\title{
Screening of Extended Spectrum Beta-Lactamase Producing Bacteria in Clinical Liquid Waste
}

\author{
Sultana $\mathrm{M}^{1}$, Naeem $\mathrm{N}^{1}$, Sultana $\mathrm{S}^{2}$, Sultana $\mathrm{KF}^{3}$, Mukharjee $\mathrm{SK}^{3}$, Hossain $\mathrm{MA}^{1}$ \\ ${ }^{1}$ Department of Microbiology, University of Dhaka, Dhaka, Bangladesh \\ ${ }^{2}$ Department of Microbiology, Jagannath University, Dhaka, Bangladesh \\ ${ }^{3}$ Department of Microbiology, Noakhali Science and Technology University, Noakhali, Bangladesh
}

e-mail: hossaina@du.ac.bd

\begin{abstract}
Admixture of Clinical Liquid Waste (CLW) discharging into Ecological Water Bodies (EWB) causes significant pollution with resistant bacteria. The issue is significant in Bangladesh where CLW management is at early stage of development. Extended-Spectrum $\beta$-Lactamase (ESBL) producing bacteria confer resistance to Broad Spectrum $\beta$-Lactam Antibiotics (BSBLA) which has become a global concern now. The aim of this study was to characterise and assess the occurrence of ESBL producing bacteria in CLW of Bangladesh. Three CLW samples were collected from two leading hospitals in Dhaka City, Bangladesh in the year 2012. A total 166 isolates were retrieved and screened for ESBL production by the Double Disk Diffusion Synergy Test (DDST). Isolates with ESBL phenotype were further characterized by antibiotic susceptibility testing, PCR and sequencing of $\beta$-lactamase genes. A total of 30 ESBL producers with Multi Drug Resistant (MDR) properties were isolated. Gene specific PCR against bla $a_{\mathrm{TEM}}, b_{\text {CTX-M }}$, and $b l a_{\mathrm{SHV}}$ detected CTX-M as major ESBL genotype (83\%) followed by occurrence of TEM-genotypes (40\%). Prevalence of SHV was low in CLW samples (3\%). More than $20 \%$ of CLW -ESBL isolates possessed both the TEM and CTX-M genotypes. The predominant ESBL isolates were phylogenetically identified as Escherichia spp. Seventy seven percent followed by Citrobacter spp. (17\%), Klebsiella spp. (3\%), and Yokenella spp. (3\%). This investigation demonstrates that CLW possesses ESBL producing MDR bacteria which might act as potential threat to disseminate resistant determinants in the surrounding environment.
\end{abstract}

Keywords: ESBL, Multidrug Resistant Bacteria, Clinical Liquid Wastewater, Ecological Water Bodies.

\section{Introduction}

Clinical Liquid Waste (CLW) includes hazardous waste materials excreted from inpatient and outpatient departments, laboratories (microbiology, biochemistry, histopathology, blood bank, etc.), operation theatres, radiology and other departments of different hospitals and clinics. The majority of antibiotics used in medicine are only partially metabolized by the patients. ${ }^{1,2}$ Thus CLW acts as the storehouse of different types of antibiotics and harmful infectious agents such as the pathogens and microorganisms possessing multidrug resistant (MDR) genes. If these hazardous CLW remains untreated and discharged directly into the ecological water bodies (EWB); it results in an increase in the active antibiotic concentration and MDR bacteria in EWB and subsequently introduces resistant gene pool to the environment. ${ }^{3}$ In recent years, the emergence of antibiotic resistant microorganisms (particularly Extended Spectrum $\beta$-Lactamase (ESBL) producing and MDR bacteria) in untreated CLW has been evidenced in Bangladesh, where CLW management is at early stage of development. ${ }^{3-5}$ This may pose a public health risk, which demands the investigation on this issue in a large extent for future evaluation and control.

Antibiotics of $\beta$-lactam group have been most widely used in infection management due to its effectiveness on a broad range of microorganisms. In Bangladesh, $\beta$-lactam antibiotics are one of the most frequently used antibiotic group but unfortunately these drugs are often sold over the 
counter without a physician's prescription. ${ }^{6}$ This indiscriminate and inappropriate use of antibiotics results in an alarming situation like the progressive loss of susceptibility towards $\beta$-lactam antibiotics in the treatment of a wide range of clinical conditions. ${ }^{7}$ The production of $\beta$ lactamases is an important mechanism of resistance to $\beta$-lactam antibiotics especially in gram negative bacteria.

Extended-Spectrum $\quad \beta$-Lactamases (ESBLs) have been contributing to the dramatic increase in resistance to new generation $\beta$-lactam agents throughout the world. ${ }^{8-11}$ Public healthcare units like hospitals and clinics must safeguard the health of the community. But in countries like Bangladesh, healthcare liquid wastes particularly CLW were laden with ESBL-MDR bacteria and seemed to pose a huge public health threat in the transfer of such resistance to the bacterial pathogens causing community acquired infections, thereby limiting our antibiotic pool. To measure the extent of these threatening microbes in the environment and followed by taking proper initiatives, a detail assessment of ESBL-MDR bacteria is required. Previous studies have shown that Escherichia coli and Klebsiella pneumoniae are the major ESBL-producing organisms worldwide while CTX-M-type enzymes were the most prevalent ESBLs. ${ }^{12-16}$ There are a few reports from Bangladesh where they found the presence of different ESBL producing gram negative bacteria in CLW. ${ }^{17-20}$ A report claims that the direct relationship between the use of antibiotics and the antibiotic resistance properties of microorganisms. ${ }^{3}$ In our previous investigation we detected the presence of ESBL within Escherichia spp. from CLW indicating that patients are spreading ESBL-MDR isolates in the environment, through hospital wastes. ${ }^{4}$ However, still there is a lack of information on molecular characterisation of ESBL producing organisms isolated from CLW in Bangladesh. Therefore, the objectives of the present study were in depth screening and char- acterisation of ESBL producing bacteria from CLW in Bangladesh.

\section{Materials and Methods}

Study area and sample collection: Three CLW samples were collected from two renowned hospitals of Dhaka city: Dhaka Medical College Hospital (DMCH) and Sir Salimullah Medical College Hospital (SSMCH). From DMCH, one sample was collected at the sewage drain of the emergency unit in February, 2012 and another sample was collected from the outdoor sewage drain in April, 2012. In June 2012, one sample was collected from SSMCH CLW-outlet which was directly connected to ecological water body river Buriganga. Each of the CLW samples were collected in a clean sterile $500 \mathrm{ml}$ Schott Duran's bottle (Schott, Germany). About $200 \mathrm{ml}$ of liquid samples containing suspended particles were collected. Collected samples were directly brought to the laboratory of the Department of Microbiology, University of Dhaka in an insulated ice box with minimum delay and were bacteriologically examined immediately.

Bacterial enumeration and isolation: Collected CLW samples sample was serially diluted up to $10^{-4}$ with sterile normal saline $(0.85 \%)$ and was used for microbiological analysis. Total viable bacterial count was determined for CLW samples using commercially available Nutrient Agar (NA) media (Oxoid, UK). MacConkey (MA) agar (Oxoid, No. 3) was used as a selective culture medium for the detection and isolation of Gram-negative bacteria from CLW samples. Amoxycillin (AM, $50 \mu \mathrm{g} / \mathrm{mL}$ ), Ciprofloxacin (CIP, $0.16 \mu \mathrm{g} / \mathrm{mL}$ ), and Cephalosporin (CEP, 5 $\mu \mathrm{g} / \mathrm{mL}$ ) antibiotics were supplemented separately to NA and MA media to determine Total Antibiotic Resistant Count (TARC), which included Total Viable Resistant Bacterial Count (TVRBC) and Total Viable Resistant Enterobacteriaceae Count (TVREC), respectively. For total Viable Bacterial Count (TVBC) no antibiotic was used in the NA and MA media. Following incubation 
at $37^{\circ} \mathrm{C}$ for $18-24$ hours, appearance of individual colony on each plate was enumerated and recorded in every case. Isolates from DMCH emergency unit outflow, outdoor sewage drain, and SSMCH outflow were designated as A, B, C respectively followed by numeric (ex: A1, B1, $\mathrm{C} 1)$.

Phenotypic detection of ESBL: All of the selected isolates from CLW were tested for ESBL production by phenotypic Double Disk Diffusion Synergy Test (DDST). ${ }^{21}$ Ceftazidime (CAZ) $(30 \mu \mathrm{g})$, Ceftriaxone (CRO) $(30 \mu \mathrm{g})$, Cefotaxime (CTX), $(30 \mu \mathrm{g})$ and Amoxycillin / Clavulanic acid, (AMC) $(30 \mu \mathrm{g})$ discs were used.

The test inoculum, turbidity matched to 0.5 Optical Density (OD) was spread on Muller-Hinton Agar (MHA) (Oxoid, UK) using a sterile cotton swab. A disc of augmenting $(20 \mu \mathrm{g}$ AM+ $10 \mu \mathrm{g}$ CLA) was placed on the center of MHA; then discs of CAZ $(30 \mu \mathrm{g})$, CRO $(30 \mu \mathrm{g})$, CTX $(30 \mu \mathrm{g})$, and AZT $(30 \mu \mathrm{g})$ were kept around it in such a way that each disc was at distance ranging between 15 and $20 \mathrm{~mm}$ from the augmented disc (Centre to Centre). The plates were incubated at $37^{\circ} \mathrm{C}$ overnight. The organisms were considered to be ESBL positive when the zone of inhibition around any of the expanded-spectrum Cephalosporin discs (CAZ/CRO/CTX) showed a clear enhancement towards the augmented disc.

Antibiotic susceptibility tests: The antimicrobial susceptibility pattern of the DDST test positive isolates that were morphologically distinct on NA was determined in vitro by using the standardized agar-disc-diffusion method known as the Kirbey-Bauer. ${ }^{22}$ It is a modification of Bauer's method. ${ }^{23}$ Sixteen different commercially available antibiotic discs belonging to 11 individual groups of antibiotics (table II) and MHA were used for the test.

PCR detection of ESBL specific gene and sequence analysis: All the isolates phenotypically positive for ESBL production were selected for detailed molecular analysis. Total DNA from the isolates were prepared as boiled DNA to use as template DNA for PCR. PCRs using primers specific for antibiotic resistance genes such as $b l a_{\text {TEM }}$ and $b l a_{\text {СTX-M }}$ were carried out using a thermal cycler (Biometra, Germany). The PCR reactions followed the protocol of Arlet et al. $1995^{24}$ and Pagani et al $2003^{25}$ for bla $b l a_{\text {CTX-M }}$ respectively. The sequence of the primers used for the PCR reactions were-bla ${ }_{\text {TEM }} \mathrm{F}$ : ATGAGTATTCAACATTTCCG and blatem R:CCAATGCTTAATCAGTGAGC; blaстх-мF: ATGTGCAGYACCAGTAARGT and blactX${ }_{\mathrm{M}} \mathrm{R}$ : TGGGTRAARTARGTSACCAGA, with the annealing temperature $55^{\circ} \mathrm{C}$ and $50^{\circ} \mathrm{C}$ respectively. Full 1ength sequences ( 858 bp for bla $a_{\mathrm{TEM}}$, and $593 \mathrm{bp}$ for bla $a_{\text {CTX-M) }}$ were assembled into using the SeqMan Genome Assembler (DNAstar, USA) and compared to the GenBank database of the National Center for Biotechnology Information (NCBI) (http://www.ncbi.nlm.nih.gov /GenBank) by means of the Basic Local Alignment Search Tool (BLAST) to identify close phylogenetic relatives. Multiple sequence alignment of the retrieved reference sequences from NCBI was performed with the ClustalW software $^{26}$ and was exported to the Molecular Evolutionary Genetics Analysis (MEGA) program ${ }^{27}$ for phylogenetic tree construction using the Neighbor joining algorithm selecting 1000 bootstrap replication.

Plasmid DNA analysis: Plasmid DNA of ESBL specific gene positive isolates was extracted using Wizard ${ }^{\circledR}$ Plus Minipreps plasmid DNA Purification kit (Promega, USA). Isolated plasmid DNA was separated in $0.8 \%$ agarose gel (ethidium bromide added) in a Tris-Acetate-EDTA (TAE) buffer and photograph was taken using GelDoc (AlphaImager, USA). Escherichia coli $\mathrm{V}_{517}$ plasmid was used as control marker plasmid DNA.

16S rRNA Gene sequencing and identification: The 16S rRNA gene of representative ESBL isolates belonging to each morphological group was amplified using primers $27 \mathrm{~F}$ and 1492R. The 
purified products were further used for sequencing and phylogenetic analysis as same as the protocol used in case of ESBL genes.

\section{Results}

Bacteriological enumeration of clinical liquid wastewater: Total Viable Bacterial Count )TVBC(, Total Viable Resistant Bacterial Count (TVRBC), and Total Viable Resistant Enterobacterial Count (TVREC) were enumerated in CLW collected from DMCH in duplicate (table I). Among TVRBC, total Cirpofloxacin (CIP) resistant count was approximately 10 times lower than total Ampicillin (AMP) or Cephalosporin (CEP) resistant viable count (table I). Metcalf $e t$ al., 1991 reported that the expected viable bacterial count in domestic sewage system is $1 \times 10^{8} \mathrm{cfu} / \mathrm{mL} .^{28}$ Values of Predicted Probable Number (PPN, the ratio of total expected viable count to total viable bacterial count) higher than one (ratio >1) indicated the presence of active antimicrobial agents in the effluents. The findings revealed that all CLW samples analyzed during this investigation had a PPN $>1$, indicating the presence of significant levels of antibiotics and other toxic compounds in the CLW.

Table I: Total and resistant bacteria count in Clinical Liquid Waste (CLW).

\begin{tabular}{|c|c|c|c|}
\hline \multirow[t]{2}{*}{ Bacterial count } & \multicolumn{3}{|c|}{$\begin{array}{l}\text { Count }(\mathrm{cfu} / \mathrm{mL}) \text { (an average } \\
\text { of duplicate plate count) }\end{array}$} \\
\hline & Sample & $\underset{2}{\text { Sample }}$ & $\underset{3}{\text { Sample }}$ \\
\hline 1. Total Viable Bacterial & $4.475 \times 1$ & $2.05 \times 1$ & $2.05 \times 10$ \\
\hline Count (TVBC) & $0^{4}$ & $0^{6}$ & 5 \\
\hline $\begin{array}{l}\text { 2. Total Enterobacteri- } \\
\text { aceae Count (TEC) }\end{array}$ & $\begin{array}{l}3.90 \times 10 \\
4\end{array}$ & $\begin{array}{l}4.45 \times 1 \\
0^{5}\end{array}$ & $6.5 \times 10^{4}$ \\
\hline \multicolumn{4}{|c|}{$\begin{array}{l}\text { 3. Total Antibiotic Resistant Count (TARC) } \\
\text { A. Total Viable Resistant Bacterial Count (TVRBC) }\end{array}$} \\
\hline $\begin{array}{l}\text { i) Total Ampicillin Resistant } \\
\text { Viable Bacterial Count } \\
\text { (TARVB) }\end{array}$ & ND & $\begin{array}{l}3.15 \\
\times 10^{5}\end{array}$ & $\begin{array}{l}1.70 \\
\times 10^{5}\end{array}$ \\
\hline $\begin{array}{l}\text { ii) Total Ciprofloxacin Re- } \\
\text { sistant Viable Bacterial } \\
\text { Count (TCRVB) }\end{array}$ & ND & $5.5 \times 10^{4}$ & $5.0 \times 10^{4}$ \\
\hline $\begin{array}{l}\text { iii) Total Cephalosporin } \\
\text { Resistant Viable Bacterial } \\
\text { Count (TCERVB) }\end{array}$ & ND & $3.0 \times 10^{5}$ & $6.0 \times 10^{4}$ \\
\hline B. Total Viable Resistant Ent & robacter & Count ( & VREC) \\
\hline $\begin{array}{lr}\text { Total Ampicillin } & \text { Resistant } \\
\text { Enterobacterial } & \text { Count } \\
\text { (TAREC) } & \end{array}$ & ND & $\begin{array}{r}1.50 \\
\times 10^{4}\end{array}$ & $6.5 \times 10^{3}$ \\
\hline $\begin{array}{l}\text { Predicted Probable Number } \\
\text { (PPN) }\end{array}$ & $>1$ & $>1$ & $>1$ \\
\hline
\end{tabular}

ND: Not detected

PPN is the quotient of Total Expected Count to Total Count that was determined using the expected count as $1 \times 10^{8} \mathrm{cfu} / \mathrm{mL}$
Isolation of ESBL producing bacteria: A total of 166 isolates from NA and MA plates were selected and tested for detection of ESBL producers by DDST. Among them, 30 isolates showed three distinguished phenotypic ESBL producing pattern (figure 1).

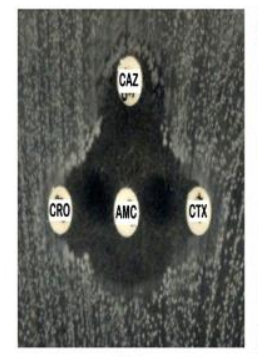

(A)

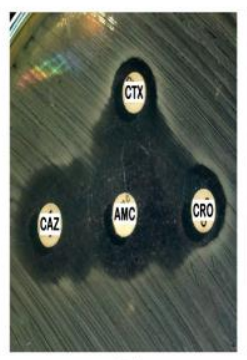

(B)

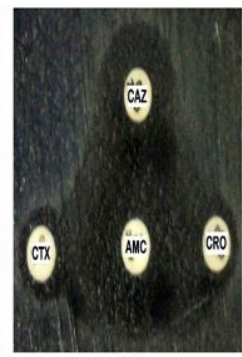

(C)
Figure 1: Distinguished patterns of Double Disk Diffusion Synergy Test (DDST) of CLW-ESBL isolates.

Representative of isolates with respective patterns are: Pattern A: C32; Pattern B: A18 and Pattern C: C49; Elaboration: CTX for Cefotaxime, CAZ for Ceftazidime, CRO for Ceftriaxone, AMC for Amoxycillin/Clavulanic acid.

These 30 ESBL positive isolates were selected for further investigation.

ESBL morphological groups and their antibiotic susceptibility pattern: According to their colony characteristics on MA media, 30 CLW-ESBL isolates were classified into four morphogroups. The four morphogroups were: dark pink and flat; pale pink and gummy; colorless; and dark pink with depression in the middle figure 2 .

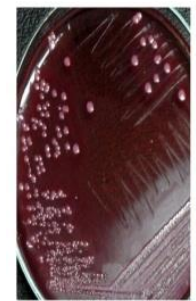

Group I

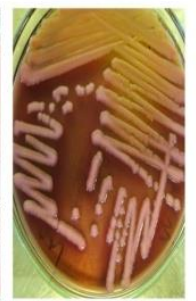

Group II

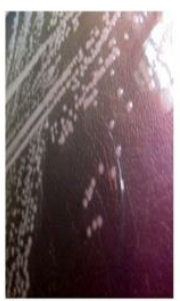

Group III

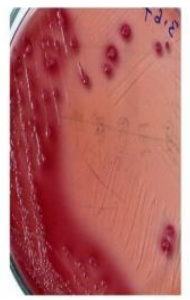

GroupIV
Figure 2: Four distinguished colony morphology of the ESBL positive isolates on MacConkey agar plates. Plate 1: Group I- dark pink and flat colonies Plate 2: Group II- pale pink and gummy colonies Plate 3: Group III- colorless small colonies Plate 4: Group IV- dark pink colonies 
Their antibiogram were analyzed against 11 different groups of antibiotics. Isolates showed maximum resistance against $\beta$-lactam group of antibiotics (Cefotaxime-CTX), followed by Penicillin group (Ampicillin-AMP and AmoxycillinAM) whereas, most of the isolates were susceptible to Imipenem-IMP and Levofloxacin-LEV.

Four morphological groups of CLW-ESBLs were distinctly different in their antibiotic resistance pattern. Group I has 23 isolates, among which 20 isolates were resistant to CTX and 16 isolates were resistant to AMP. Group II had one isolate A20, which was resistant to AMP, TET, CIP, FEP, and CTX. Group III had one isolate A16, which showed resistance against AMP and CTX, and sensitive to all other antibiotics tested. Group IV has five isolates and all of them were resistant to AMP, CTX, and CAZ.

Table II: Four morphogroups of ESBL isolates showing variations in their drug resistance pattern and genotyping of $\beta$-lactamases genes.

\begin{tabular}{|c|c|c|c|c|c|}
\hline $\begin{array}{c}\text { Source } \\
\text { Morphological groups of } \\
\text { CLW ESBLs } \\
\end{array}$ & $\begin{array}{l}\text { Isolate } \\
\text { ID }\end{array}$ & Antibiotic Resistance Pattern & $\begin{array}{c}\text { bla }_{\text {tem }} \\
(853 \\
\text { bp) } \\
\end{array}$ & $\begin{array}{c}\text { bla }_{\text {ctx-M }} \\
(593 \\
\text { bp) }\end{array}$ & $\begin{array}{c}\text { bla }_{\text {shv }} \\
(827 \\
\text { bp) }\end{array}$ \\
\hline \multirow[t]{23}{*}{ Gr. I; Dark pink and flat } & A12 & $\begin{array}{l}\text { AMP, TET, N, CIP, AZM, AZT, FEP, CTX, } \\
\text { CAZ }\end{array}$ & + & + & - \\
\hline & A18 & AMP, TET, ATM, FEP, CTX, CAZ & - & + & - \\
\hline & A19 & AMP, N, CTX & - & + & - \\
\hline & A22 & AMP, N, AZM, FEP, CTX & - & + & - \\
\hline & B2 & IMP, AZT, FEP, CTX, CAZ & - & + & - \\
\hline & B4 & AMP & + & - & - \\
\hline & B7 & $\begin{array}{l}\text { AMP, TET, CIP, AZM, IMP, AZT, FEP, } \\
\text { CTX, CAZ }\end{array}$ & - & + & - \\
\hline & B15 & AZT, CTX, CAZ & - & + & - \\
\hline & B18 & AZT, CTX, CAZ & - & + & - \\
\hline & B24 & AMP, AZT, CRO & + & - & - \\
\hline & B29 & AZT, FEP, CAZ & - & + & - \\
\hline & B57 & CTX, CAZ & + & + & - \\
\hline & C6 & $\begin{array}{l}\text { AMP, TET, N, CIP, AZM, AK, AZT, C, FEP, } \\
\text { CTX, CAZ }\end{array}$ & + & + & - \\
\hline & $\mathrm{C} 13$ & AMP, N, AZT, FEP, CTX, CAZ, CRO & + & - & - \\
\hline & C32 & AMP, AZT, FEP, CTX, CAZ, CRO & - & + & - \\
\hline & C39 & $\begin{array}{l}\text { AMP, TET, AZM, AZT, FEP, CTX, CAZ, } \\
\text { CRO }\end{array}$ & - & + & - \\
\hline & $\mathrm{C} 47$ & IMP, FEP, CTX & + & + & - \\
\hline & $\mathrm{C} 49$ & AMP, TET, N, CIP, AZM, CTX & + & + & - \\
\hline & C57 & ATM, FEP, CTX, CAZ & - & + & - \\
\hline & $\mathrm{C} 72$ & AMP, CIP, AZM, ATM, CTX, CAZ & + & - & - \\
\hline & C79 & AMP, CIP, CTX & - & + & - \\
\hline & $\mathrm{C} 84$ & AMP, CIP, AZM, ATM, FEP, CTX & - & + & - \\
\hline & $\mathrm{C} 100$ & AMP, CTX & + & + & - \\
\hline Gr. II:Pale pink and gummy & A20 & AMP, TET, CIP, FEP, CTX & + & + & - \\
\hline Gr. III:Colorless & A16 & AMP, CTX & - & - & - \\
\hline \multirow[t]{5}{*}{$\begin{array}{l}\text { Gr. IV:Dark pink with a de- } \\
\text { pression in the middle }\end{array}$} & A3 & $\begin{array}{l}\text { AMP, TET, N, CIP, AK, IMP, AZT, FEP, } \\
\text { CTX, CAZ }\end{array}$ & + & + & - \\
\hline & $\mathrm{C} 18$ & AMP, AZT, FEP, CTX, CAZ & - & + & + \\
\hline & C67 & $\begin{array}{l}\text { AMP, TET, CIP, AZM, AZT, FEP, CTX, } \\
\text { CAZ, CRO }\end{array}$ & - & + & - \\
\hline & $\mathrm{C} 70$ & AMP, TET, AK, AZT, FEP, CTX, CAZ, CRO & - & + & - \\
\hline & $\mathrm{C} 92$ & AMP, CTX, CAZ & - & + & - \\
\hline
\end{tabular}

Amoxycillin (AM), Ampicillin (AMP), Amikacin (AK), Azithromycin (AZM), Aztreonam (AZT), Cirpofloxacin (CIP), Levofloxacin (LEV), Chloramphenicle (C), Cefepime (FEP), Cefotaxime (CTX), Ceftazidime (CAZ), Ceftriaxone (CRO), Cefixime (CFM), Imipenem (IMP), Nitrofuran (N), Tetracycline (TET)

Analysis of extended spectrum $\beta$-Lactamase (ESBL) Genes: The prevalent ESBL genotype was lla $_{\mathrm{CTX}-\mathrm{M}}$ type, $83 \%$ of among the total iso- lates (table II, figure 3). The frequency of bla $a_{\text {TEM }}$ genotype was $40 \%(12 / 30)$ and only $3 \%$ (1/30) were positive for bla $a_{\text {SHv }}$ gene (table II). On 
the other hand, $23 \%$ of the isolates had both bla $a_{\text {TEM }}$ and $b l a_{\text {СTX-м }}$ genes.

Sequencing and homology search using Gen Bank database of the ESBL specific bla $a_{\mathrm{TEM}}$ and bla $a_{\text {CTX-M }}$ genes showed that all TEM positive isolates were $100 \%$ similar to TEM-1 enzyme of Escherichia coli strain AS713010 (JN037848.1). All CTX positive isolates showed $100 \%$ similarity with Escherichia coli strain BLSE2012CF1 CTX-M-15 (figure 2).

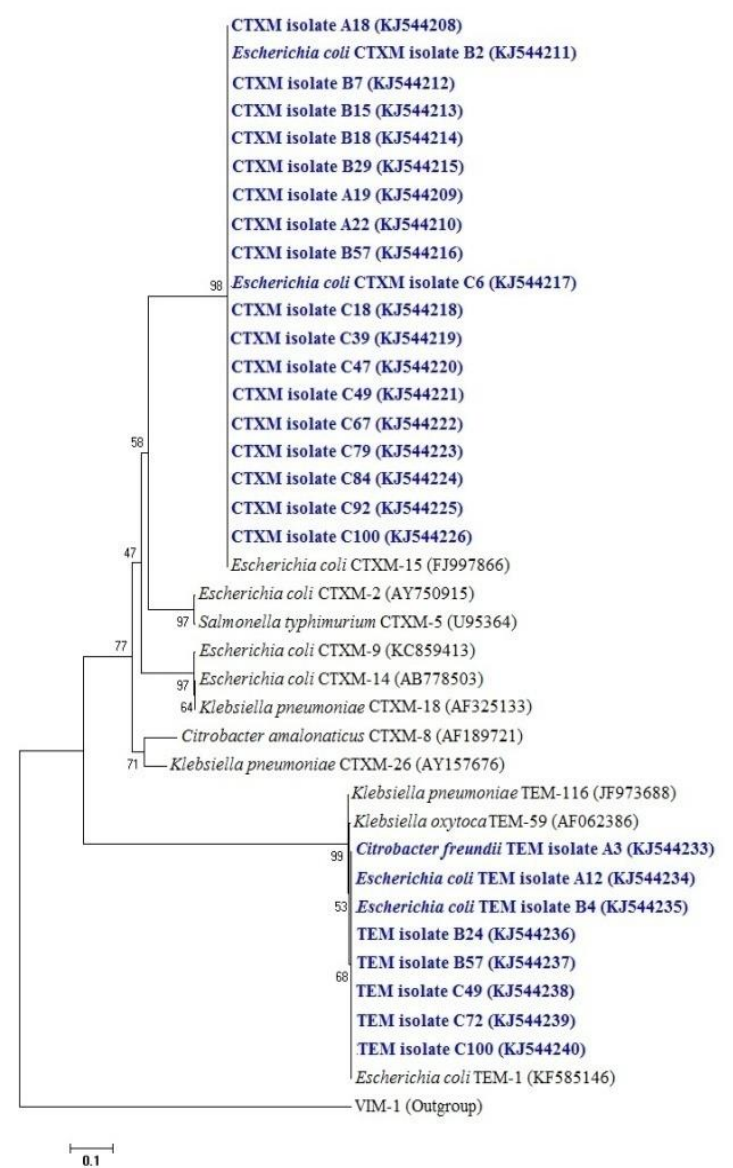

Figure 3: Phylogenetic placement of $\beta$ lactamase genes (bla $a_{\mathrm{TEM}}$ and bla $_{\mathrm{CTX}-\mathrm{M}}$ ).

The evolutionary history was inferred using the Neighbor-Joining method. The optimal tree with the sum of branch length $=1.48188406$ is shown. The percentage of replicate trees in which the associated taxa clustered together in the bootstrap test (1000 replicates) are shown next to the branches. Evolutionary analyses were conducted in MEGA5.

Accession number of NCBI submitted ESBLTEM positive isolates are KJ544233-40 and ESBL- CTX positive isolates are KJ544208-26.

Plasmid Profile of ESBL Isolates: Among 30 ESBL positive MDR isolates seven isolates were plasmid free. They included: B4, B24, C32, C79, C84, and C100 (morphogroup I) and A20 (morphogroup III). Large plasmids above the chromosomal range were found in seven isolates. Among them, isolate A18 contains only a large size plasmid, whereas, others contain three or more small size plasmids at varying size ranges.

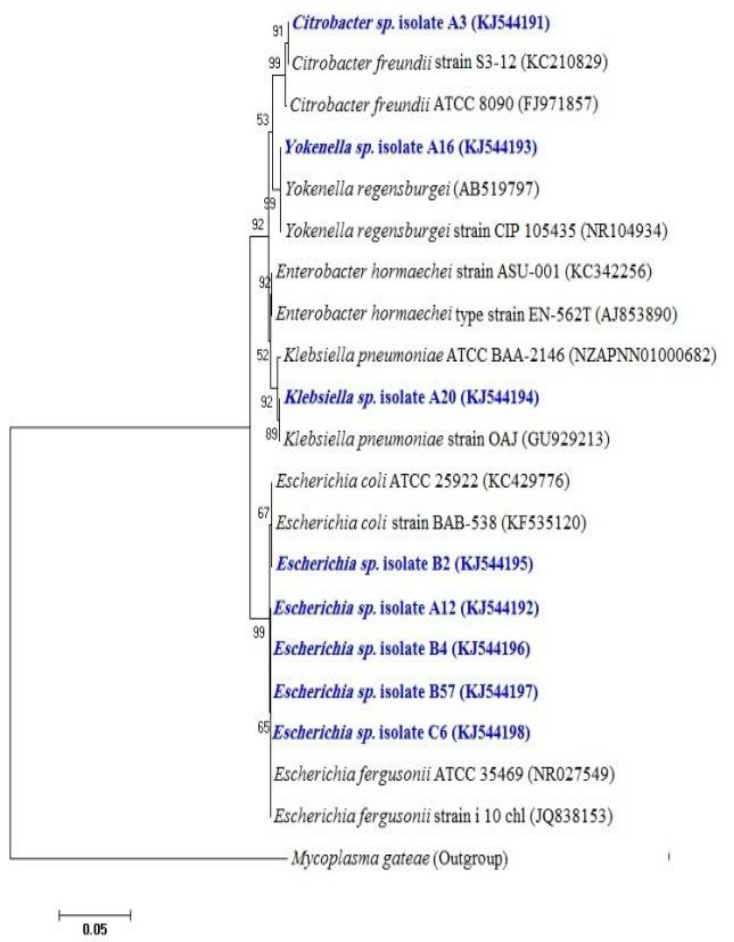

Figure 4: Phylogenetic placement of 16S rRNA gene sequences of ESBL positive isolates.

The evolutionary history was inferred using the Neighbor-Joining method. The optimal tree with the sum of branch length $=1.48188406$ is shown. The percentage of replicate trees in which the associated taxa clustered together in the bootstrap test (1000 replicates) are shown next to the branches. Evolutionary analyses were conducted in MEGA5.

16S rRNA gene identification of ESBL positive $C L W: 16 \mathrm{~S}$ rRNA gene sequences of isolates A12, B2, B4, B57, and C6 from the dominant morphogroup, Group I of CLW-ESBL (figure 4, table II) clustered with Escherichia spp. specifically with Escherichia fergusonii except isolate B2 which was more closely related to Escherichia coli (figure 5). Isolate A20 of group II, A16 of group III and A3 of group IV were closely related to Klebsiella sp, Yokenella sp. and Citrobacter $s p$., respectively (figure 3). Accession number of 
NCBI submitted 16s rRNA gene sequences of CLW-ESBL isolates are KJ544191-98.

Table III: Number and size of plasmids from ESBL isolates of CLW samples

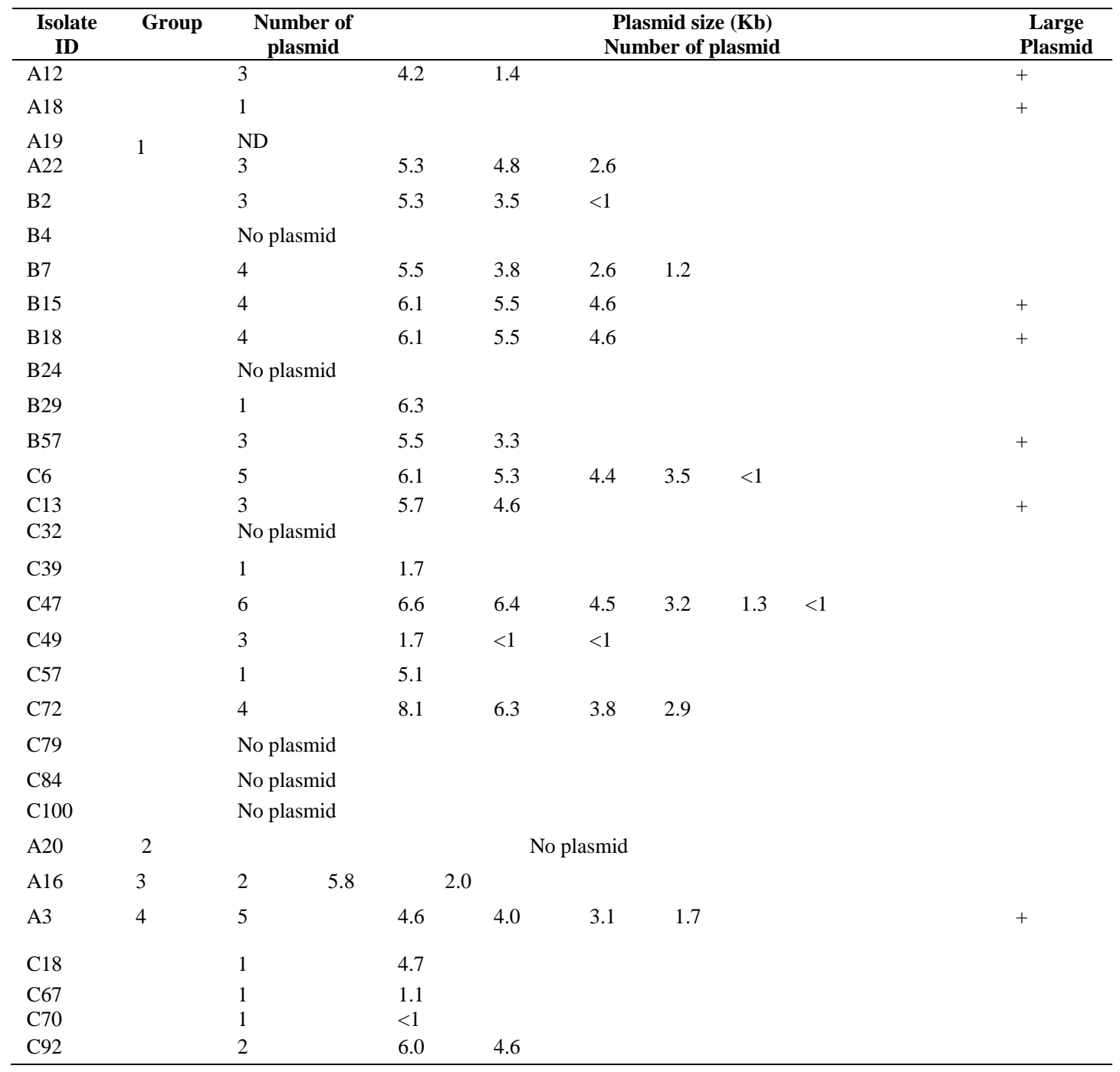

\section{Discussion}

In Bangladesh, mostly CLW is directly released into municipal sewage system and subsequently discharged into the ecological water bodies. CLW contains resistant pathogenic bacteria and non-metabolized antimicrobial agents. To understand the contribution of CLW in the pollution of ecological water bodies, this investigation demonstrated that i) Predicted Probable Number (PPN) microbial populations in CLW was lower than the expected value; ii) CLW contained MDR and ESBL producing bacteria with CTX$M$ and TEM specific dominant genotypes; iii) the predominant species were Escherichia spp.,
Klebsiella spp. and Citrobacter spp. ; and iv) Antibiotic resistance properties might be both plasmid mediated and chromosomal borne.

In Bangladesh, all CLW originated from hospitals, veterinaries, and other sources directly or via municipality drainage system are discharged into ecological water bodies resulting serious pollutions of environment with resistant bacteria and resistant gene pool pollutions. In the ecological water bodies, bacteria from different sources like CLW, agriculture, urban and industrial wastewater are mixed together and genetic exchange between the environmental species and allochthonous species may occur resulting new 
pathogenic bacteria of clinical importance. ${ }^{29}$ Recently, the presence of antimicrobial-resistant bacteria in different ecological niches in Bangladesh has been reported. ${ }^{29}$ Therefore, this problem has been assessed in current study, and the samples consisted of pathogenic and antibiotic resistant bacteria (table I). In this study, bacterial concentration in the CLW was found to be lower than $10^{8} \mathrm{cfu} / 100 \mathrm{~mL}$ (table I), indicating the presence of antimicrobial agents in CLW. ${ }^{28}$ Our recent quantitative analysis of antibiotics concentrations in CLW clearly demonstrated that CLW contained different antibiotics at $\mathrm{MIC}_{50}$ or sub$\mathrm{MIC}_{50}$ levels (unpublished). Furthermore, these resistant bacteria contained transferable resistant markers. As a result, there remains a potential risk of resistant bacteria and resistant gene pool pollution of the environment. ${ }^{4}$ The admixing of CLW with ecological water bodies like river, ponds, cannel, lakes etc. may cause serious pollutions and become a subject of clinical importance because this pollution cycles through food-chain and water. ${ }^{30}$

In the present study, three different ESBL phenotypes for each of $30 \mathrm{ESBL}$ positive isolates were observed and some additional isolates susceptible to CAZ, CRO, CTX and AMC (A22, B4, B24 and B57) were confirmed as ESBLs through genotypic screening. ESBLs are typically recognized for their unusual antibiotic resistance to their hosts, but there are also reports suggesting intermediate or even susceptible phenotype. ${ }^{31}$ Among the $61 \mathrm{ESBL}$ isolates, $61 \%$ isolates were Escherichia spp. and $11 \%$ were Klebsiella spp. CLW samples predominantly contained Escherichia spp. (figure 4). Among 30 CLW-ESBLs, 77\% Escherichia spp. And 3\% Klebsiella spp. were found. Yokenella spp. (3\%) and Citrobacter spp. (17\%) were less prevalent and have barely been reported as ESBL producers. Although Yokenella spp. has been reported from the environment, their presence in clinical settings is very recent $^{32}$ and therefore underestimated as a clinically significant pathogen or even ESBLs. The present study is so far the first report of Yokenella spp. from Bangladesh as ESBL producer.

The dominant genotype of ESBL among the three ESBL coding genes (bla $a_{\mathrm{TEM}}$, bla $_{\mathrm{CTX}-\mathrm{M}}$, and blasHV), were detected to be CTX-M type followed by TEM genotype. Among the 61 ESBL isolates, $83 \%, 40 \%$, and $13 \%$ of CLW isolates were $b l a_{\mathrm{CTX}-\mathrm{M}}, b l a_{\mathrm{TEM}}$, and $b l a_{\mathrm{SHV}}$ types, respectively (Table II). Simultaneous presence of bla $a_{\text {TEM }}$ and $b l a_{\text {СTX-м }}$ genes was detected in $27 \%$ of CLW isolates. Phylogenetically, it was observed that TEM1 and CTX-M-15 types were predominant in Bangladesh samples (figure 4). In India, CTX-M-15 genotype was reported to be dominant within E. coli $(75 \%)$ and Klebsiella spp. $(73 \%) .{ }^{33}$ Simultaneous presence of bla $a_{\mathrm{CTX}-\mathrm{M}}$ and $b l a$ TEM was reported from hospital waste water and clinical samples in Brazil. ${ }^{34}$ The dominance or co-dominance of CTX-M gene within the isolates may be due to overuse of ceftriaxone or due to fecal carriage and transfer gene by horizontal transmission. ${ }^{33-35}$

ESBLs are reported as mutant enzymes originating from TEM or SHV enzymes and can be plasmid mediated. ${ }^{36}$ Bacteria can resist $\beta$-lactam antibiotics with the help of hydrolyzing enzymes, $\beta$-lactamases, which can be chromosome mediated, too. ${ }^{37-39}$ In the current study, many of the ESBL isolates harbored multiple plasmids, indicating that the multidrug resistance properties of the isolates might be plasmid borne. Seven of the phenotypically and genotypically confirmed ESBL isolates from CLW did not harbor plasmid under the experimental conditions but they had a multidrug resistance profile (table II). This indicated the possibility of chromosomal inheritance of ESBL enzyme and other antibiotic resistance genes. ESBL producing strains contain MDR plasmids that may easily be transmitted between members of Enterobacteriaceae, consequently ESBL producing organisms are resistant to a variety of classes of antibiotics. As a result of horizontal gene transfer (HGT) by mobile genetic elements such as plasmids, transposons, and by transduction, non-ESBL producing pathogens might become potent ESBL producing pathogens, which is of significant concern because this event may evolve new and clinically important pathogenic bacteria. ${ }^{29}$

\section{Conclusion}

The present investigation analyzes a comparative perspective of phenotypic and genotypic ESBL producing bacteria from CLW in Bangladesh. The dominant ESBL producers in CLW samples from Bangladesh were detected to be Escherichia spp. and the dominant genotype was of CTX-M15 type. The ESBL properties as well as multi- 
drug resistance phenomena can be either chromosome or plasmid mediated. The epidemiology of ESBL-producing bacteria is a growing concern in Bangladesh with increasingly blurred boundaries between hospitals and the community. So, there is an urgent need to monitor and control the spread of ESBLs in the environment.

Acknowledgements: Authors gratefully acknowledge the support of University Grants Commission (UGC) of Bangladesh and Ministry of Science and Technology (MOST), Dhaka for conduction of the study. Authors also thankful to TWAS for equipment grant.

\section{References}

1. Golet EM, Xifra I, Siegrist H, Alder AC, Giger W. Environmental exposure assessment of fluoroquinolone antibacterial agents from sewage to soil. Environmental science \& technology. 2003;37(15):324349.

2. Martinez JL. Environmental pollution by antibiotics and by antibiotic resistance determinants. Environmental pollution. 2009; 157(11):2893-902.

3. Islam M, Uddin M, Hakim M, Das K, Hasan M. Role of untreated liquid hospital waste to the development of antibiotic resistant bacteria. J Innov Dev Strategy. 2008;2 (2):17-21.

4. Adnan N, Sultana M, Islam OK, Nandi SP, Hossain MA. Characterization of Ciprofloxacin resistant Extended Spectrum [Beta]-Lactamase (ESBL) producing Escherichia spp. from clinical waste water in Bangladesh. Advances in Bioscience and Biotechnology. 2013; 4(7B):15

5. Akter F, Amin MR, Osman KT, Anwar MN, Karim MM, Hossain MA. Ciprofloxacin-resistant Escherichia coli in hospital wastewater of Bangladesh and prediction of its mechanism of resistance. World Journal of Microbiology and Biotechnology. 2012;28(3):827-34.

6. Rahman MM, Haq JA, Hossain MA, Sultana R, Islam F, Islam AH. Prevalence of extendedspectrum beta-lactamase-producing Escherichia coli and Klebsiella pneumoniae in an urban hospital in Dhaka, Bangladesh. International journal of antimicrobial agents.2004; $24 \quad$ (5):508-10. doi:10.1016/j.ijantimicag.2004.05.007

7. Okeke IN, Lamikanra A, Edelman R. Socioeconomic and behavioral factors leading to acquired bacterial resistance to antibiotics in developing countries. Emerging infectious diseases. 1999; 5(1):18.
8. Bradford PA. Extended-spectrum $\beta$-lactamases in the 21st century: characterization, epidemiology, and detection of this important resistance threat. Clinical microbiology reviews. 2001; 14(4):933-51.

9. Bush K. New beta-lactamases in gram-negative bacteria: diversity and impact on the selection of antimicrobial therapy. Clin Infect Dis.2001; 32 (7):1085-89.

10. Perez F, Endimiani A, Hujer KM, Bonomo RA. The continuing challenge of ESBLs. Current opinion in pharmacology. 2007;7(5):459-69.

11. Paterson DL. Resistance in gram-negative bacteria: Enterobacteriaceae. The American Journal of Medicine. 2006; 119(6):S20-S28.

12. Hernández J, Martinez-Martinez L, Cantón R, Coque T, Pascual A, Infections SGfN. Nationwide study of Escherichia coli and Klebsiella pneumoniae producing extended-spectrum $\beta$-lactamases in Spain. Antimicrobial agents and chemotherapy. 2005; 49 (5):2122-25.

13. Mugnaioli C, Luzzaro F, De Luca F, Brigante G, Perilli M, Amicosante G, et al. CTX-M-type extended-spectrum $\beta$-lactamases in Italy: molecular epidemiology of an emerging countrywide problem. Antimicrobial agents and chemotherapy. 2006; 50(8):2700-06.

14. Radice M, Power P, Di Conza J, Gutkind G. Early dissemination of CTX-M-derived enzymes in South America. Antimicrobial agents and chemotherapy. 2002; 46 (2):602-04.

15. Ryoo NH, Kim E-C, Hong SG, Park YJ, Lee K, Bae IK, et al. Dissemination of SHV-12 and CTX-Mtype extended-spectrum $\beta$-lactamases among clinical isolates of Escherichia coli and Klebsiella pneumoniae and emergence of GES-3 in Korea. Journal of Antimicrobial Chemotherapy. 2005;56 (4):698702 .

16. Rawat D, Nair D. Extended-spectrum B-lactamases in gram negative bacteria. Journal of global infectious diseases. 2010;2 (3):263.

17. Ashfaq KMA, Pijush S, Majharul IM, Kant OR, Chandra BG. Screening of antibiotic resistant gram negative bacteria and plasmid profiling of multidrug resistant isolates present in sewage associated with health care centers. International Journal of Medical Research \& Health Sciences. 2013;2 (4):923-30.

18. Lina TT, Khajanchi BK, Azmi IJ, Islam MA, Mahmood B, Akter M, et al. Phenotypic and Molecular Characterization of Extended-Spectrum BetaLactamase-Producing Escherichia coli in Bangladesh. PloS one. 2014; 9(10):e108735. 
19. Mowla R, Imam KA-H, Asaduzzaman M, Nasrin N, Raihan SZ, Chowdhury AA. Emergence of multidrug resistant extended-spectrum $\beta$-lactamase producing Eshcherichia coli associated with urinary tract infections in Bangladesh. Journal of basic and clinical pharmacy. 2011; 3(1):225.

20. Yesmin T, Hossain M, Paul S, Mahmud C, Kabir M, Haque N, et al. Prevalence and antimicrobial susceptibility pattern of ESBL producing isolates. MMJ. 2013;22(4):625-31.

21. Jarlier V, Nicolas M-H, Fournier G, Philippon A. Extended broad-spectrum $\beta$-lactamases conferring transferable resistance to newer $\beta$-lactam agents in Enterobacteriaceae: hospital prevalence and susceptibility patterns. Review of Infectious Diseases. 1988; 10 (4):867-78.

22. Barry AL, Thornsberry C. Susceptibility tests: Diffusion test procedures. In: Lennette EH, Balows A, Hausler Jr WJ, Shadomy HJ, eds. . Manual of Clinical Microbiology. 1985; 978-87

23. Bauer A, Kirby W, Sherris JC, Turck M. Antibiotic susceptibility testing by a standardized single disk method. American Journal of Clinical Pathology. 1966;45(4):493.

24. Arlet G, Brami G, Decre D, Flippo A, Gaillot O, Lagrange $P$, et al. Molecular characterisation by PCR-restriction fragment length polymorphism of TEM $\beta$-lactamases. FEMS Microbiology Letters. 1995; 134(2-3):203-08.

25. Pagani L, Dell'Amico E, Migliavacca R, D'Andrea MM, Giacobone E, Amicosante G, et al. Multiple CTX-M-type extended-spectrum $\beta$-lactamases in nosocomial isolates of Enterobacteriaceae from a hospital in northern Italy. Journal of Clinical Microbiology. 2003; 41(9):4264-69.

26. Larkin MA, Blackshields G, Brown N, Chenna R, McGettigan PA, McWilliam H, et al. Clustal W and Clustal X version 2.0. Bioinformatics. 2007; 23(21):2947-48.

27. Tamura K, Dudley J, Nei M, Kumar S. MEGA4: molecular evolutionary genetics analysis (MEGA) software version 4.0. Molecular Biology and Evolution. 2007; 24(8):1596-99.

28. Metcalf E. Wastewater engineering treatment, disposal and reuse McGraw-Hill book co. Singapore; 1991.
29. Lupo A, Coyne S, Berendonk TU. Origin and evolution of antibiotic resistance: the common mechanisms of emergence and spread in water bodies. Analyzing possible intersections in the resistome among human, animal and environment matrices. 2012:116.

30. Rashid M, Rakib MM, Hasan B. Antimicrobialresistant and ESBL-producing Escherichia coli in different ecological niches in Bangladesh. Infection Ecology \& Epidemiology. 2015;5.

31. Philippon A, Labia R, Jacoby G. Extended-spectrum beta-lactamases. Antimicrobial Agents and Chemotherapy. 1989;33(8):1131.

32. Lo Y-C, Chuang Y-W, Lin Y-H. Yokenella regensburgei in an immunocompromised host: a case report and review of the literature. Infection. 2011;39 (5):485-88.

33. Ensor V, Shahid M, Evans J, Hawkey P. Occurrence, prevalence and genetic environment of CTXM $\beta$-lactamases in Enterobacteriaceae from Indian hospitals. Journal of Antimicrobial Chemotherapy. 2006; 58(6):1260-63.

34. Cavaco L, Abatih E, Aarestrup FM, Guardabassi L. Selection and persistence of CTX-M-producing Escherichia coli in the intestinal flora of pigs treated with amoxicillin, ceftiofur, or cefquinome. Antimicrobial agents and chemotherapy. 2008; 52(10):3612-16.

35. Pitout JD, Laupland KB. Extended-spectrum $\beta$ lactamase-producing Enterobacteriaceae: an emerging public-health concern. The Lancet Infectious Diseases. 2008;8(3):159-66.

36. Sirot D. Extended-spectrum plasmid-mediated $\beta$ lactamases. Journal of Antimicrobial Chemotherapy. 1995;36(suppl A):19-34.

37. Bonnet R. Growing group of extended-spectrum $\beta$ lactamases: the CTX-M enzymes. Antimicrobial Agents and Chemotherapy. 2004;48(1):1-14.

38. Bush K, Jacoby GA. Updated functional classification of $\beta$-lactamases. Antimicrobial Agents and Chemotherapy. 2010; 54(3):969-76.

39. Pitout JD, Laupland KB, Church DL, Menard ML, Johnson JR. Virulence factors of Escherichia coli isolates that produce CTX-M-type extendedspectrum $\beta$-lactamases. Antimicrobial Agents and Chemotherapy. 2005; 49(11):4667-70. 